\title{
Polymorphism of L-FABP (SNP g. 1593 C>T) Gene and Its Association with Fatty Acid Composition, Carcass, and Meat Quality in Cihateup Duck
}

\author{
A. S. Mentaria , A. Gunawan ${ }^{\mathrm{b}}$, \& R. R. Noor ${ }^{\mathrm{b}, *}$ \\ aGraduate School of IPB University (Bogor Agricultural University) \\ bepartment of Animal Production and Technology, Faculty of Animal Science, IPB University \\ (Bogor Agricultural University) \\ Jalan Agatis, Kampus IPB Dramaga Bogor 16680, Indonesia \\ *Corresponding author: ronny_noor@yahoo.com \\ (Received 09-07-2018; Revised 30-10-2019; Accepted 20-11-2019)
}

\begin{abstract}
Fatty acid composition, carcass, and meat quality are quantitative traits which are controlled by several genes or polygenic. One of the genes that plays important role in the fatty acid in meat quality and fatty acid composition is liver-type fatty acid-binding protein (L-FABP). The aims of this study were to identify single nucleotide polymorphism (SNP) of liver-fatty acid binding protein (L-FABP) gene and its association with fatty acid, carcass, and meat quality traits in cihateup duck. Cihateup ducks were originated from Tasikmalaya, West Java, Indonesia. The study used a total of 98 ducks aged of 12 weeks old with the average body size of $1.4 \pm 0.12 \mathrm{~kg}$ for PCR-RFLP analyses and 76 ducks for the association analyses. Polymerase Chain Reaction-Restriction Fragment Length Polymorphism (PCR-RFLP) was used to identify SNP g. 1593 (C>T) of L-FABP gene. The associations of L-FABP genotypes with fatty acid, carcass, and meat quality traits were performed using T-test procedures. The result showed that the SNP of L-FABP gene was polymorphic with three genotypes (CC, CT, and TT). The Chi-square test revealed that the locus of L-FABP (g. $1593 \mathrm{C}>\mathrm{T}$ ) was in Hardy - Weinberg equilibrium. L-FABP gene was significantly associated $(\mathrm{p}<0.01)$ with the carcass portions, providing neck and percentage of neck as well as significantly associated $(p<0.05)$ with saturated fatty acids, i.e., lauric acid $(C 12: 0)$ and palmitic acid (C 16:0); polyunsaturated fatty acid, i.e., eicosadienoic acid (C 20:2); carcass portions, i.e. neck and percentage of neck. The SNP g. 1593 (C>T) of L-FABP gene may be a useful marker for selecting and producing duck meat having desirable fatty acids and carcass and meat quality.
\end{abstract}

\section{Keywords: L-FABP gene; fatty acid; meat quality; Cihateup duck}

\section{INTRODUCTION}

Poultry production in the year of 2017 in Indonesia, including broiler, layer, native chicken, and ducks were around 1,848.1, 114.0, 296.2, and 43.2 tons, respectively (DITJENNAK, 2017). The data showed that the production of meat duck was lower than the chicken products. The lower consumption of meat duck can be influenced by several reasons such as high flavor and odor and saturated fatty acid composition in duck meat which are associated with negative effect for human health (Anggraeni et al., 2017).

Fatty acid content of duck meat such as saturated fatty acid (SFA), monounsaturated fatty acid (MUFA), or polyunsaturated fatty acid (PUFA) is one of the factors that increases mortality caused by cardiovascular disease (Ferre, 2019). SFA intake could not be a major factor for cardiovascular disease, even though SFA intakes are in the higher ranges in a population. Meanwhile, by increasing PUFA intake is related to a lower risk of fatal cardiovascular disease, whether changing SFA, in contrast the effect of MUFA on cardiovascular risk is warranted (Virtanen et al, 2014). Ebrahimi et al. (2018) stated that linoleic acid (C 18:2, C20:4 and C22:6) included into PUFA showed a positive correlation to carcass quality and associated to human's health as well.

In order to produce a desirable and healthy meat for consumers, selecting genes that affect fatty acid, carcass, and meat quality can be done. Those traits are regulated by poly genes. One of the genes that control the fatty acid in meat quality and fatty acid composition is liver-type fatty acid-binding protein (L-FABP). The L-FABP is a member of family intracellular fatty acidbinding protein (iLBPs) which transport fatty acid from the plasma membrane to $\beta$ oxidation site and to triglyceride or phospholipid synthesis (He et al., 2011). The L-FABP gene may be used as one of genetic markers for selecting fatty acid composition in meat due to its role in transporting saturated and unsaturated fatty acid. Previous study by Martin et al. (2013) indicated that the L-FABP could bind two amino acids per molecule, different from any types of fatty acid-binding protein. L-FABP could bind neither fatty acid nor hydrophobic ligands including acyl -CoA, bilirubin, lyso-phosphatidyl-choline, bile salt, prostaglandin, and peroxisome proliferator. He et al. (2011) stated that the L-FABP had a 
great potential to be used as a genetic marker which was related to fatty acid composition based on the previous research in Beijing duck, Shaoxing, Muscovy, Mallard, $\mathrm{Ma}$, and its progeny. L-FABP polymorphisms were reported to be related to fatty acid such as C16:0, C18:3, and total IMF in chest muscle, where CC genotype had higher contents when compared to CT and TT genotypes (He et al., 2011). The effect on marbling in white swine showed that the polymorphism had a significant effect in genotype $\mathrm{CC}$ where it had more marbling than TC, and TC had more marbling than TT; besides, the effect on intramuscular fat content was also polymorphic, it showed that L-FABP might be a candidate gene associated with meat quality traits (Zhang et al., 2013). However, this gene and its effect on the quality of duck carcasses has never been explored in Indonesian local ducks. The aims of this study were to identify single nucleotide polymorphism (SNP) of liver-fatty acid binding protein (L-FABP) gene and its association with the fatty acid, carcass and meat quality traits in cihateup duck.

\section{MATERIALS AND METHODS}

\section{Animals and Samples}

A total 98 Cihateup ducks consisted of 39 males and 59 females were used in this observation. All ducks had average body weight of $1.4 \mathrm{~kg}(1472.7 \pm 120.2 \mathrm{~g})$ and aged of 12 weeks and were reared in the same condition and feed with the water given ad libitum. The ducks were slaughtered according to the animal welfare ethics with the performance test guidelines IPO number 132016 (Anggraeni et al., 2017). The whole blood samples were collected from vena brachialis of Cihateup ducks. The genotyping was conducted at the Laboratory of Animal Breeding and Genetics, Faculty of Animal Science, IPB University, Indonesia. A total of $100 \mu \mathrm{L}$ of blood samples and $100 \mathrm{~g}$ of meat samples were taken for DNA extraction and fatty acids analyses. All samples were kept in refrigerator at $4^{\circ} \mathrm{C}$ until further analyses.

\section{Analysis of Fatty Acid, Carcass, and Meat Quality}

Data of fatty acid composition (total fatty acids, saturated fatty acids, monounsaturated fatty acids, and polyunsaturated fatty acids), carcass and meat quality ( $\mathrm{pH}$, color, cooking, \% free $\mathrm{H}_{2} \mathrm{O}$ (water holding capacity), MDA/malonaldehyde, and TMA/trimethylamine) used the data analyzed and reported previously by Anggraeni et al. (2017).

\section{DNA Extraction and Polymerase Chain Reaction - Restriction Fragment Length Polymorphism (PCR-RFLP)}

The g. 1593 (C > T) SNP of L-FABP gene used in this study referred to the previous study by He et al. (2011). DNA extraction was conducted using a standard procedure referred to Sambrook et al. (1989). The principle of DNA extraction was started by destroying the cell walls and the cell membranes in order to gain DNA in the nucleus without causing damage to the DNA. Basically,
DNA extractions were separated into several stages namely the preparation of material, the process of cell destruction, the removal of contaminant compounds, and the DNA collection. Extracted DNAs have to be free from contaminant compounds which were frequently carried along and could be inhibit the work of several enzymes in molecular activity.

PCR was performed for amplification of the polymorphic region of L-FABP gene. A pair of primers were designed manually based on Viljoen et al. (2015) and PCR suitability tests were checked using Primer Stat. These primers (forward and reverse), 5'-GCATGAGTGAAGCCTGTTTG-3' and 3'-CCTGTA GATGACAATACAGC-5', respectively, were used to amplify a 590 base pairs (bp) fragment according to the anas genomic sequence in the GeneBank database (accession number HQ640427). The PCR was performed under the following conditions. Initial denaturation at $95^{\circ} \mathrm{C}$ for 5 minutes in 1 cycle. The second phase consisted of 35 cycles, each cycle consisting of denaturation process at $95^{\circ} \mathrm{C}$ for 20 seconds, primer annealing at $58^{\circ} \mathrm{C}$ for 30 seconds, and DNA extension at $72^{\circ} \mathrm{C}$ for 30 seconds. The final phase was the primer elongation or final extension at $72^{\circ} \mathrm{C}$ for 5 minutes. The DNA amplification product of $590 \mathrm{bp}$ was visualized by using $1.5 \%$ agarose gel electrophoresis.

PCR products from polymorphic region of L-FABP gene (590 bp) were digested with $\mathrm{BfaI}$ restriction enzyme which was selected based on the software (http://tools.neb.com/NEBcutter2/index.php) of the polymorphic sites. PCR products and BfaI were incubated at $37^{\circ} \mathrm{C}$ for 2 hours (Thermo Fisher Scientific, EU, Lithuania). The products of DNA fragments from PCRRFLP were visualized using $2 \%$ agarose gel electrophoresis, electrophoresis was run on average voltage of 100 volts for 45 minutes. The product of PCR were visualized under ultra-violet transilluminator (Alpha Imager, Alpha Innotech, Santa Clara, USA).

\section{Statistical Analysis}

The genotype and allele frequencies were analyzed based on the genotyping data of Cihateup duck using the formula of Nei \& Kumar (2000):

$$
\begin{gathered}
\mathrm{x}_{\mathrm{ii}}=\frac{\sum_{\mathrm{i}=1}^{\mathrm{n}} \mathrm{n}_{\mathrm{i}}}{\mathrm{N}} \\
\mathrm{x}_{\mathrm{i}}=\frac{\left(2 \mathrm{n}_{\mathrm{ii}}+\sum_{i \neq j} n_{i j}\right)}{2 \mathrm{~N}}
\end{gathered}
$$

Where was the $i^{\text {th }}$ allele frequency, was $i^{\text {th }}$ genotype frequency, $i$ was the frequency of allele $i^{\text {th }}$; was the total individuals with genotype $i i$; total individuals with genotype $i j$ and $\mathrm{N}$ was the population size. Hardy-Weinberg equilibrium (H-W) (Hartl \& Clark, 1997):

$$
\chi^{2}=\sum_{i=1}^{N} \frac{(O-E)^{2}}{E}
$$

Where $X^{2}$ was Chi Squared; O was total of observed genotypes and $\mathrm{E}$ was total of expected genotypes and $i$ was the number of observations $(\mathrm{N}=98)$. 


\section{Association Analysis}

Due to the nonsignificant (Pvalue $>0.05$ ) effect of the sex on fatty acid, carcass and meat quality, association between the SNP of L-FABP gene and fatty acid, carcass and meat quality traits was performed using T-test procedure using Minitab statistical analysis Software.

$$
\begin{gathered}
t=\frac{\bar{X}_{1}-\bar{X}_{2}}{S \sqrt{\frac{1}{n_{1}}+\frac{1}{n_{2}}}} \\
\text { Where } S=\sqrt{\frac{\sum_{i=1}^{n}\left(\overline{X_{i}}-\overline{X_{1}}\right)^{2}+\sum_{i=1}^{n}\left(\overline{X_{i}}-\overline{X_{2}}\right)^{2}}{n_{1}+n_{2}-2}}
\end{gathered}
$$

Note: $\bar{X}_{1}$ and $\bar{X}_{2}$ were the average traits for genotype 1 and genotype $2, n_{1}$ and $n_{2}$ were individual number of genotype 1 and 2, and $S$ was the combined of standard deviation.

\section{RESULTS}

\section{L-FABP Gene Polymorphism}

Amplification of the fragment of the L-FABP gene in cihateup duck using PCR with BfaI enzyme and the L-FABP SNP g.1593 C > T at exon 3 is presented in Figure 1. The length of L-FABP product was $590 \mathrm{bp}$ fragment of DNA (Figure 1).

The fragment of the L-FABP gene in Cihateup duck showed 3 genotypes which were CC, CT, and TT. DNA amplification with genotype CC had 2 fragments which were $249 \mathrm{bp}$ and $341 \mathrm{bp}$, while genotype CT had three fragments which were $299 \mathrm{bp}, 341 \mathrm{bp}$, and $590 \mathrm{bp}$, and genotype TT had one fragment which was $590 \mathrm{bp}$ (Figure 2). The L-FABP gene at exon 3 had one single nucleotide polymorphism (SNP) as was detected by CTAG cut site, by using BfaI enzyme. Fragments were separated by electrophoresis $2.0 \%$ agarose gel. Change of cytosine $(\mathrm{C})$ to thymine $(\mathrm{T})$ was happened at point g.1593 $\mathrm{C}>\mathrm{T}$ at exon 3 known as a substitution of transition base.

Genotype and allele frequencies were calculated based on the polymorphisms of L-FABP gene at exon 3 SNP g.1593 C>T in cihateup duck. The C allele frequency was higher than that of the $\mathrm{T}$ allele. The distribution of genotype and allele frequencies for L-FABP in cihateup duck are prensented in Table 1 . The highest genotype frequency was the CC (0.48), followed by CT (0.40) and TT (0.12). The C allele frequency was 0.68 and $\mathrm{T}$ allele frequency was 0.32 . Based on the HardyWeinberg equilibrium test the allele frequencies were in the equilibrium state $\left(\chi^{2}\right.$ value $\left.=0.75\right)$.

\section{Association of L-FABP Gene Polymorphisms and Fatty Acid Traits in Cihateup Duck}

The analysis of fatty acid compositions for association provided saturated fatty acid (SFA), monounsaturated fatty acid (MUFA), and polyunsaturated fatty acid (PUFA7). The genotype of meat fatty acid traits in Cihateup duck are presented in Table 2.

The g.1593 C>T SNP of L-FABP gene was significantly $(\mathrm{p}<0.05)$ associated with lauric acid $(\mathrm{C} 12: 0)$, palmitic acid (C16:0), and eicosadienoic acid (C20:2). In general, the T-test showed that the individuals with

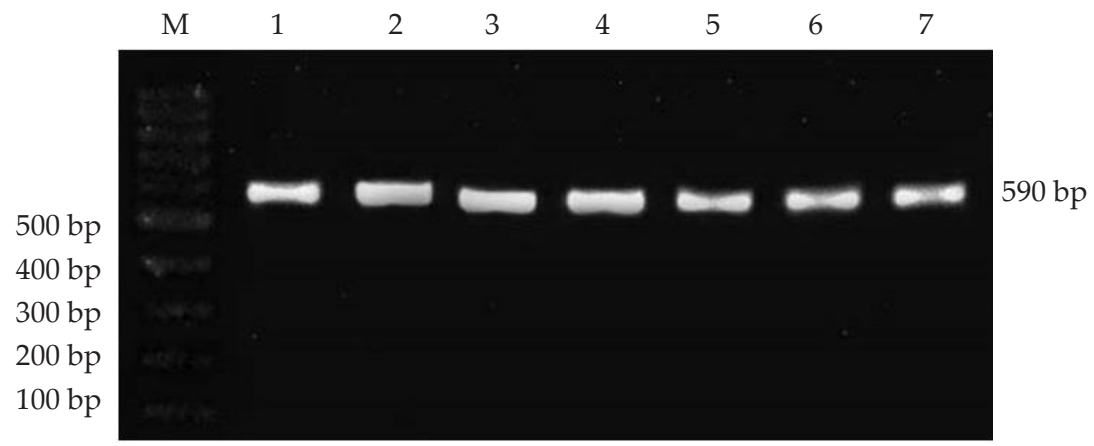

Figure 1. Amplification result of PCR for L-FABP gen on 1.5\% gel agarose; $\mathrm{M}=100 \mathrm{bp}$ ladder size standard; Line 1-7= individual duck samples.

M CT СС СТ СТ СС ТT CC

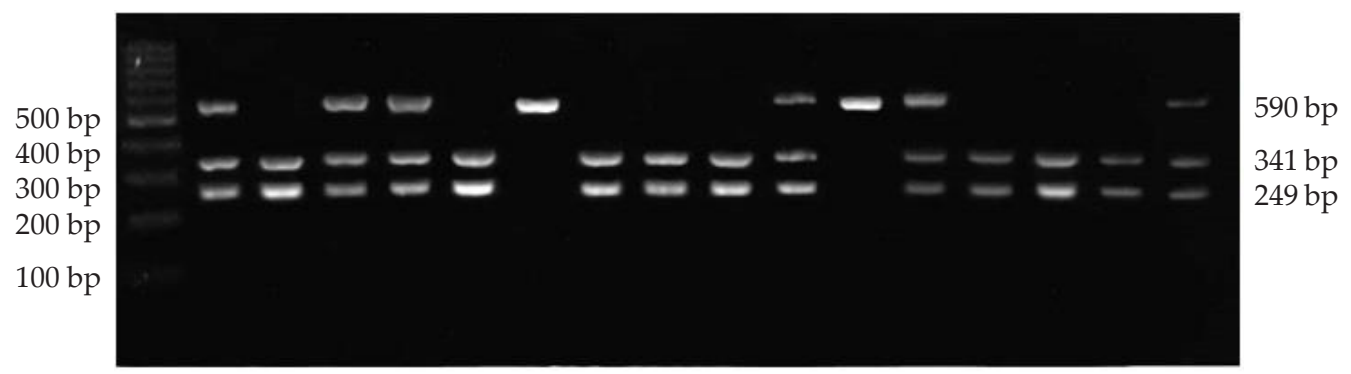

Figure 2. PCR-RFLP analysis of $590 \mathrm{bp}$ fragment of L-FABP gene by BfaI restriction enzyme on $2 \%$ agarose gel. CC: CC genotype; CT: CT genotype; TT: TT genotype; M: DNA marker $100 \mathrm{bp}$. 
homozygous CC genotype were associated with lower saturated fatty acid (SFA) and monounsaturated fatty acid (MUFA) $(\mathrm{p}<0.05)$ but with a higher polyunsaturated fatty acid (PUFA) (Table 2 and Table 3 ).

\section{Association of L-FABP Gene Polymorphism with Carcass and Meat Quality Traits in Cihateup Duck}

In this study, the CC genotype had the lowest averages of body and carcass weights when compared to the CT and TT genotypes (Table 4). Based on the T-test analyses among genotypes, it showed that the genotypes significantly affected the neck and percentage of neck (Table 5). The g.1593 C>T SNP of L-FABP gene was associated with neck $(\mathrm{p}>0.01)$ where TT genotype was higher than the $\mathrm{CC}$ and the percentage of neck where the TT genotype was higher than CC. The percentage of neck of CT genotype was higher than that of the CC genotype (Table 5).

The average of meat quality traits showed normal range values (Table 6). Meat quality traits including color, $\mathrm{pH}$, cooking loss, water activity, MDA, TMA, and crude protein influence consumer preferences related to organoleptic assessment. The g.1593 C>T SNP of L-FABP gene was significantly $(p<0.05)$ associated with $\mathrm{L}^{*}$ (indicates lightness) where the TT genotype had higher $\mathrm{L}^{*}$ (indicates lightness) value than the CT (Table 6). However, this association should be further validated with a larger samples size and more expert panelists.

\section{DISCUSSION}

The L-FABP gene showed a higher frequency of C allele than the $\mathrm{T}$ allele (Table 1). The higher frequency of allele $C$ could be due to a nonrandom mating, selection, mutation, random drift, and small population size (Noor, 2010; Gunawan et al., 2017). The result shows that the L-FABP gene in cihateup duck is polymorphic as the allele frequencies of $\mathrm{C}$ and $\mathrm{T}$ are less than 0.99 . These results are in agreement with Hartl \& Clark (1997) that an allele is categorized as a polymorphic if the frequency of its allele is less than 0.99. According to Bohle

Table 1. Genotype, allele frequencies, and Chi-squared of L-FABP gene g.1539 (C>T) SNP) in Cihateup duck

\begin{tabular}{|c|c|c|c|c|c|c|c|}
\hline \multirow{2}{*}{ Gene } & \multirow{2}{*}{$\mathrm{N}$} & \multicolumn{3}{|c|}{ Genotype frequencies } & \multicolumn{2}{|c|}{ Allele frequencies } & \multirow{2}{*}{$\begin{array}{l}\text { Chi-squared }(\chi 2) \\
\text { value }\end{array}$} \\
\hline & & CC (n) & $\mathrm{CT}(\mathrm{n})$ & TT (n) & $\mathrm{C}$ & $\mathrm{T}$ & \\
\hline L-FABP & 98 & $0.48(47)$ & $0.40(39)$ & $0.12(12)$ & 0.68 & 0.32 & $0.75^{\text {ns }}$ \\
\hline
\end{tabular}

Note: $n s=$ not significant $(\mathrm{p}<0.05) \cdot \chi 2=$ Chi-square: Chi-square from table $=5.991(\mathrm{p}<0.05)$, degree of freedom $(\mathrm{df})$ is equal to the number of expected genotypes -1 , number of genotypes is 3 and $\mathrm{df}=2$.

Table 2. Phenotype of meat fatty acid traits in Cihateup duck*

\begin{tabular}{lrrr}
\hline \multirow{2}{*}{ Variables } & \multicolumn{3}{c}{ Average $( \pm$ S.D) $(\%)$} \\
\cline { 2 - 4 } & $\mathrm{CC}(\mathrm{n}=22)$ & $\mathrm{CT}(\mathrm{n}=17)$ & $\mathrm{TT}(\mathrm{n}=6)$ \\
\hline Saturated fatty acid & $32.40 \pm 1.61$ & $32.84 \pm 2.41$ & $32.91 \pm 2.54$ \\
(SFA) & & & \\
Lauric acid (C12:0) & $15.81 \pm 5.16$ & $15.86 \pm 5.92$ & $10.02 \pm 5.53$ \\
Myristic acid (C14:0) & $0.53 \pm 0.03$ & $0.50 \pm 0.05$ & $0.51 \pm 0.05$ \\
Pentadecanoic acid & $0.05 \pm 0.01$ & $0.04 \pm 0.01$ & $0.04 \pm 0.01$ \\
(C15:0) & & & \\
Palmitic acid (C16:0) & $2.05 \pm 0.43$ & $2.14 \pm 0.56$ & $2.53 \pm 0.53$ \\
Heptadecanoic acid & $0.09 \pm 0.01$ & $0.10 \pm 0.01$ & $0.09 \pm 0.01$ \\
(C17:0) & & & \\
Stearic acid (C18:0) & $4.49 \pm 0.72$ & $4.31 \pm 0.65$ & $4.84 \pm 0.91$ \\
Arachidic acid (C20:0) & $0.19 \pm 0.05$ & $0.18 \pm 0.03$ & $0.20 \pm 0.01$ \\
Monounsaturated fatty & $47.14 \pm 2.58$ & $46.75 \pm 2.33$ & $47.47 \pm 4.02$ \\
acid (MUFA) & & & \\
Palmitoleic acid (C16:1) & $27.58 \pm 1.46$ & $27.37 \pm 2.12$ & $26.86 \pm 2.42$ \\
Oleic acid (C18:1n9c) & $44.26 \pm 2.39$ & $43.72 \pm 2.05$ & $44.14 \pm 3.69$ \\
Polyunsaturated fatty & $18.88 \pm 1.36$ & $18.78 \pm 1.36$ & $18.45 \pm 1.39$ \\
acid (PUFA) & & & \\
Linoleic acid (C18:2n6c) & $18.44 \pm 1.38$ & $18.35 \pm 1.35$ & $17.94 \pm 1.41$ \\
Linolenic acid (C18:3n3) & $0.04 \pm 0.01$ & $0.04 \pm 0.01$ & $0.04 \pm 0.01$ \\
Elaidic acid (C18:1n9t) & $0.12 \pm 0.03$ & $0.12 \pm 0.03$ & $0.11 \pm 0.01$ \\
Eicosadienoic acid & $6.51 \pm 2.08$ & $6.72 \pm 1.49$ & $5.22 \pm 1.63$ \\
(C20:2) & & & \\
Arachidonic acid & $0.05 \pm 0.02$ & $0.05 \pm 0.02$ & $0.06 \pm 0.03$ \\
(C20:4n6) & & & \\
Eicosaenic acid (C20:1) & $0.70 \pm 0.14$ & $0.76 \pm 0.12$ & $0.68 \pm 0.11$ \\
\hline
\end{tabular}

Note: *The components that cannot be analyzed are minor/trace. It could be amino acid or some parts of fatty acids that does not mentioned in this table.
Table 3. Genotype and association analyses of L-FABP gene with fatty acid traits

\begin{tabular}{lccc}
\hline Variables & \multicolumn{3}{c}{ Probability value } \\
\cline { 2 - 4 } & CC vs CT & CC vs TT & CT vs TT \\
\hline Saturated fatty acid (SFA) & 0.402 & 0.560 & 0.947 \\
Lauric acid (C12:0) & 0.977 & $0.018^{*}$ & $0.036^{*}$ \\
Myristic acid (C14:0) & 0.121 & 0.396 & 0.769 \\
Pentadecanoic acid (C15:0) & 0.245 & 0.083 & 0.194 \\
Palmitic acid (C16:0) & 0.586 & $0.025^{*}$ & 0.133 \\
Heptadecanoic acid & 0.321 & 0.578 & 0.199 \\
(C17:0) & & & \\
Stearic acid (C18:0) & 0.433 & 0.303 & 0.118 \\
Arachidic acid (C20:0) & 0.682 & 0.923 & 0.369 \\
Monounsaturated fatty & 0.628 & 0.803 & 0.585 \\
acid (MUFA) & & & \\
Palmitoleic acid (C16:1) & 0.727 & 0.349 & 0.609 \\
Oleic acid (C18:1n9c) & 0.463 & 0.921 & 0.721 \\
Polyunsaturated fatty acid & 0.808 & 0.471 & 0.599 \\
(PUFA) & & & \\
Linoleic acid (C18:2n6c) & 0.854 & 0.422 & 0.508 \\
Linolenic acid (C18:3n3) & 0.740 & 0.795 & 0.616 \\
Elaidic acid (C18:1n9t) & 0.977 & 0.670 & 0.720 \\
Eicosadienoic acid (C20:2) & 0.737 & 0.147 & $0.040^{*}$ \\
Arachidonic acid (C20:4n6) & 0.397 & 0.313 & 0.143 \\
Eicosaenic acid (C20:1) & 0.169 & 0.672 & 0.136 \\
\hline
\end{tabular}

Note: p-value with different superscripts in the same row $\left({ }^{*}\right)$ differ significantly at $p<0.05$. Numbers shown in parentheses are the number of individuals with the specified genotype. 
Table 4. Phenotype of carcass characteristics of different genotypes in Cihateup duck

\begin{tabular}{|c|c|c|c|}
\hline \multirow{2}{*}{ Variables } & \multicolumn{3}{|c|}{ Average $( \pm$ S.D) } \\
\hline & $C C(n=30)$ & $\mathrm{CT}(\mathrm{n}=26)$ & $\mathrm{TT}(\mathrm{n}=6)$ \\
\hline Body weight (g) & $1455.00 \pm 147.00$ & $1466.70 \pm 98.50$ & $1517.40 \pm 57.10$ \\
\hline Head (g) & $82.22 \pm \quad 7.72$ & $84.85 \pm 8.06$ & $91.38 \pm 6.95$ \\
\hline$\%$ Head & $5.80 \pm 0.48$ & $6.11 \pm 0.38$ & $6.23 \pm 0.27$ \\
\hline Neck (g) & $78.70 \pm 8.99$ & $83.30 \pm 10.90$ & $89.75 \pm 5.92$ \\
\hline$\%$ Neck & $5.29 \pm 0.39$ & $5.81 \pm 0.66$ & $5.81 \pm 0.09$ \\
\hline Carcass (g) & $916.00 \pm 127.00$ & $946.00 \pm 114.00$ & $931.30 \pm 85.00$ \\
\hline$\%$ Carcass & $62.87 \pm \quad 4.98$ & $64.36 \pm \quad 5.05$ & $61.32 \pm 4.12$ \\
\hline Wing (g) & $132.00 \pm 14.80$ & $132.40 \pm 11.90$ & $133.25 \pm 9.25$ \\
\hline$\%$ Wing & $8.72 \pm \quad 0.87$ & $9.04 \pm 0.68$ & $8.87 \pm 0.42$ \\
\hline Breast (g) & $246.60 \pm 58.70$ & $237.60 \pm 47.90$ & $228.10 \pm 25.80$ \\
\hline$\%$ Breast & $26.91 \pm 5.24$ & $25.15 \pm \quad 3.93$ & $24.59 \pm 2.82$ \\
\hline Shank (g) & $235.10 \pm 31.50$ & $229.90 \pm 29.60$ & $232.10 \pm 23.50$ \\
\hline
\end{tabular}

Table 6. Meat quality of different genotypes in Cihateup duck

\begin{tabular}{lrrr}
\hline \multirow{2}{*}{ Variables } & \multicolumn{3}{c}{ Average $( \pm$ S.D $)$} \\
\cline { 2 - 4 } & \multicolumn{1}{c}{$\mathrm{CC}(\mathrm{n}=30)$} & \multicolumn{1}{c}{$\mathrm{CT}(\mathrm{n}=26)$} & \multicolumn{1}{c}{$\mathrm{TT}(\mathrm{n}=6)$} \\
\hline $\mathrm{L}^{*}$ & $39.58 \pm 0.79$ & $39.24 \pm 0.91$ & $40.15 \pm 0.55$ \\
$\mathrm{a}^{*}$ & $18.75 \pm 1.34$ & $18.97 \pm 1.48$ & $18.44 \pm 1.57$ \\
$\mathrm{~b}^{*}$ & $3.19 \pm 0.57$ & $3.22 \pm 0.61$ & $3.06 \pm 0.60$ \\
$\mathrm{pH}$ & $5.51 \pm 0.16$ & $5.48 \pm 0.15$ & $5.47 \pm 0.13$ \\
$\mathrm{Cooking}$ & $48.26 \pm 3.89$ & $47.18 \pm 5.04$ & $48.50 \pm 5.09$ \\
loss $(\%)$ & & & \\
$\% \mathrm{H}_{2} \mathrm{O}$ & $27.25 \pm 2.70$ & $26.93 \pm 2.38$ & $28.11 \pm 2.89$ \\
$\mathrm{MDA}$ & $1.27 \pm 0.35$ & $1.32 \pm 0.34$ & $1.15 \pm 0.23$ \\
$\mathrm{TMA}$ & $7.57 \pm 1.18$ & $7.09 \pm 1.13$ & $6.96 \pm 0.52$ \\
$\mathrm{CP}(\%)$ & $25.99 \pm 4.27$ & $24.52 \pm 3.48$ & $25.04 \pm 2.74$ \\
\hline
\end{tabular}

Note: $\mathrm{L}^{*}$ (indicates lightness), $\mathrm{a}^{*}$ (the red/green coordinate), $\mathrm{b}^{*}$ (the yellow/blue coordinate $)=$ indicator of meat color; $\mathrm{pH}=$ relative humidity; $\% \mathrm{H}_{2} \mathrm{O}=$ water activity; $\mathrm{MDA}$ and TMA= indicator of offodor; $\mathrm{CP}=$ crude protein

and Gabaldon (2012) polymorphisms could be used as genetic markers in a population.

This study revealed three genotypes for the L-FABP gene in Cihateup duck namely CC, CT, and TT. In previous study He et al. (2011) found polymorphism in Beijing, Shaoxing, Muscovy, and Mallard duck with CC, $\mathrm{CT}$, and TT genotypes. This study explained that the association was related to the fatty acid compositions, C16:0, C18:3, and total IMF in breast muscle where the CC genotype was significantly higher than CT and TT genotypes. In contrast, this study demonstrated that the CC genotype had a lower value of C16:0 than the CT and TT genotypes. On the other hand, the C18:3 indicated almost similar values (Table 2 and 3). Beside the genetic factor, the feeding management could be one of the factors that influence fatty acid compositions (Poulsen et al. 2012).

L-FABP gene in Cihateup duck affected the lauric and palmitic acid contents (Table 3). Praagman et al. (2019) stated that the lauric acid (C12:0), myristic acid (C14:0), and palmitic acid (C16:0) influenced cardiovascular health. In addition, the eicosedienoic acid that was included to PUFA showed significant result where geno-
Table 5. Genotype and association analyses of L-FABP gene with carcass characteristics

\begin{tabular}{lccc}
\hline \multirow{2}{*}{ Variables } & \multicolumn{3}{c}{ Probability value } \\
\cline { 2 - 4 } & CC vs CT & CC vs TT & CT vs TT \\
\hline Body weight (g) & 0.739 & 0.256 & 0.178 \\
Head (g) & 0.226 & 0.005 & 0.046 \\
\% Head & 0.084 & 0.063 & 0.503 \\
Neck (g) & 0.099 & $0.003^{* *}$ & 0.118 \\
\% Neck & $0.027^{*}$ & $0.001^{* *}$ & 0.992 \\
Carcass (g) & 0.366 & 0.695 & 0.742 \\
\% Carcass & 0.281 & 0.427 & 0.130 \\
Wing (g) & 0.904 & 0.819 & 0.855 \\
\% Wing & 0.309 & 0.709 & 0.576 \\
Breast (g) & 0.541 & 0.398 & 0.597 \\
\% Breast & 0.167 & 0.240 & 0.710 \\
Shank (g) & 0.533 & 0.806 & 0.846 \\
\hline
\end{tabular}

Note: p-value with different superscripts in the same row differ significantly at $\mathrm{p}<0.05\left({ }^{*}\right)$ and at $\mathrm{p}<0.01\left({ }^{* *}\right)$. Numbers shown in parentheses are the number of individuals with the specified genotype.

Table 7. Genotype and association analyses of L-FABP gene with meat quality traits

\begin{tabular}{lccc}
\hline \multirow{2}{*}{ Variables } & \multicolumn{3}{c}{ Probability value } \\
\cline { 2 - 4 } & CC vs CT & CC vs TT & CT vs TT \\
\hline $\mathrm{L}^{*}$ & 0.202 & 0.112 & $0.029^{*}$ \\
$\mathrm{a}^{*}$ & 0.588 & 0.600 & 0.418 \\
$\mathrm{~b}^{*}$ & 0.848 & 0.594 & 0.537 \\
$\mathrm{pH}$ & 0.457 & 0.596 & 0.964 \\
$\mathrm{Cooking} \mathrm{loss}$ & 0.389 & 0.892 & 0.546 \\
$\% \mathrm{H}_{2} \mathrm{O}$ & 0.662 & 0.465 & 0.281 \\
$\mathrm{MDA}$ & 0.717 & 0.426 & 0.292 \\
TMA & 0.217 & 0.238 & 0.797 \\
$\mathrm{CP}$ & 0.171 & 0.558 & 0.702 \\
\hline
\end{tabular}

Note: p-value with different superscripts $\left({ }^{*}\right)$ in the same row differ significantly at $p<0.05$. Numbers shown in parentheses are the number of individuals with the specified genotype. $\mathrm{L}^{*}$ (indicates lightness), $a^{*}$ (the red/green coordinate), $b^{*}$ (the yellow/blue coordinate $)=$ indicator of meat color; $\mathrm{p}=$ relative humidity; $\% \mathrm{H}_{2} \mathrm{O}=$ water activity; MDA and TMA= indicator of off-odor; $\mathrm{CP}=$ crude protein.

type CT had higher values than the TT (Table 3). PUFA has a function to control hepatic PPAR $\alpha$ and SREBP-1c which regulate fatty acid in human body (Jump et al., 2013).

Overall, the result showed the average value of SFA in Cihateup duck meat was higher than that of PUFA but lower than that of MUFA in all genotypes (Table 2). This result is in agreement with the current study by Briggs et al. (2017) that generally fatty composition of duck has higher SFA value when compared to the PUFA but has lower value than the MUFA. Consuming more SFA, MUFA, PUFA, and cholesterol will increase the low density lipoprotein (LDL) in blood, and also increase the risk of coronary heart disease. Roussell et al. (2012) showed that the change in consuming beef to chicken meats would significantly decrease the apolipoprotein $B$ and total cholesterol levels in microalbumin of type 2 diabetic patient because of the PUFA level in chicken 
meat is higher than in beef. However, it also depends on the ratio of omega 6 (linoleic acid) and omega 3 (linolenic acid) which ideally around 4:1. Despite of the normal result of linoleic and linolenic acid contents in Cihateup duck meat, it is far beyond the ratio to support the PUFA function.

In previous observation by $\mathrm{He}$ et al. (2012), it was reported that the mutation in L-FABP gene could affect carcass quality in some breeds of ducks, and polymorphisms of SNP in exon 3 L-FABP gene in duck were related to the fatty acid compositions; C16: 0, C18: 3, and total intramuscular fat in pectoral muscle. L-FABP has interaction with protein transportation, regulation of transcription gene, growth and differentiation, signal transduction, and cellular protection (Atshaves et al., 2010).

The results demonstrated that the carcass characteristic significantly affected the neck and percentage of neck. While the average of body weight and carcass showed slight differences among genotypes. Orellana et al. (2009) stated that the carcass fats including thickness and intramuscular fat were affected by meat fatty acid profile which would affect carcass weight indirectly. Costa et al. (2018) showed that the fatty acids including myristic (C14:0), palmitoleic (C16:1), and heptadecenoic $(\mathrm{C} 17: 1)$ would increase with the increased carcass weight, whereas stearic acid (C18:0) would decrease with the increased carcass weight. However, the result in this study showed that the lauric acid (12:0), palmitic acid (16:0), and eicosedienic (C20:2) were affected by the genotype (Table 2). Thus, the relation between the fatty acid compositions with carcass weight in L-FABP gene of Cihateup duck was not revealed yet.

The meat quality traits are generally within the normal range values (Table 6). However, the $\mathrm{L}^{*}$ color (lightness of the meat) of the TT is higher than the CT (Table 7). The meat color influences the appearance and consumer preferences and it depends on pigment content. The dimensions for measuring meat color are: first, hue angle that represents the kind of color; chroma or saturation that represents depth of color or the extent to which the hue is diluted with black; and lightness $\left(\mathrm{L}^{*}\right)$ that represents the extent to which the hue is diluted with white (AMSA, 2012). Wideman et al. (2016) stated that the color of poultry meat was influenced by total heme and myoglobin contents, $\mathrm{pH}$, age/sex of birds, breed, diet, rearing, and processing. However, no information for direct effect between the L-FABP gene and meat color. However, the function of L-FABP gene which regulates lipid oxidation might be one of factors that influences meat color indirectly. Kerry \& Ledward (2009) stated that heme protein oxidation precipitated by the secondary lipid oxidation gave a positive correlation between metmyoglobin formation and lipid oxidation. The reason for aldehyde-induced myoglobin oxidation might be related to the abduction of the modification of amino acids. The aldehyde, 4-hydroxynonenal is recently being used as a model for exploring lipid oxidation-induced meat discoloration.

\section{CONCLUSION}

L-FABP gene was polymorphic in Cihateup duck with $C$ allele was more frequent in population. The SNP g.1593 C>T of L-FABP gene affected the fatty acids contents including the saturated fatty acids, i.e., lauric acid (C12:0) and palmitic acid (C16:0); polyunsaturated fatty acids, i.e., eicosadienoic acid (C 20:2); carcass portions, i.e. neck and percentage of neck. The SNP (g.1593 C>T) of L-FABP gene might be a useful marker for selecting and producing desirable and healthy duck meat.

\section{CONFLICT OF INTEREST}

Asep Gunawan serves as an editor of the Tropical Animal Science Journal, but has no role in the decision to publish this article. We also certify that there is no conflict of interest with any financial, personal, or other relationships with the other people or organization related to the material discussed in the manuscript.

\section{ACKNOWLEDGEMENT}

We are especially grateful to Dr. Ir. Anggraeni, M.Si for the help by preparing duck samples and providing technical assistance during the research.

\section{REFERENCES}

AMSA. 2012. Meat Color Measurement Guidlines. American Meat Science Association, USA.

Anggraeni, A. Gunawan, Rukmiasih, T. Suryati, \& C. Sumantri. 2017. Association and expression analyses of the duck FMO3 gene in relation to fatty acid composition. Int. J. Poult. Sci. 16: 486-493. https://doi.org/10.3923/ ijps.2017.486.493

Atshaves, B. P., G. G. Martin, H. A. Hostetler, A. L. McIntosh, A. B. Kier, \& F. Schroeder. 2010. Liver fatty acid binding protein and obesity. J. Nutr. Biochem. 11: 1015-1032. https://doi.org/10.1016/j.jnutbio.2010.01.005

Bohle, H. M. \& T. Gabaldon. 2012. Selection of marker genes using whole-genome DNA polymorphism analysis. Evo. Bioinfo. 8: 161-169. https://doi.org/10.4137/EBO.S8989

Briggs, M.A., K. S. Petersen, \& P. M. Kris-Etherton. 2017. Saturated fatty acids and cardiovascular disease: replacements for saturated fat to reduce cardiovascular risk. Healthcare. 5: 1-29. https://doi.org/10.3390/ healthcare5020029

Costa, J. B., R. L. Oliveira, T. M. Silva, A. M. Barbosa, M. S. Borja, C. B. de Pellergrini, V. da S. Oliveira, R. D. X. Ribeiro, \& L. R. Bazerra. 2018. Fatty acid, physicochemical composition and sensory attributes of meat from lambs fed diets containing licuri cake. PloS One. 11: 1-15. https://doi. org/10.1371/journal.pone.0206863

Direktorat Jendral Peternakan dan Kesehatan Hewan Kementerian Pertanian. 2017. Statistik dan Kesehatan Hewan. Kementrian Pertanian RI, Jakarta.

Ebrahami, M., M. A. Rajion, S. Jafari, M. F. Jahromi, E. Oskoueian, A. Q. Sazili, Y. M. Goh, \& M. H. Ghaffari. 2018. Effect of dietary n-6: n-3 polyunsaturated fatty acid ration on meat quality, carcass characteristics, tissue fatty acid profiles, and expression of lipogenic genes in growing goats. PloS One. 8: 1-21. https://doi.org/10.1371/journal. pone.0188369 
Ferre, M. G., G. Zong, W. C. Willet, P. L. Zock, A. J. Wanders, F. B. Hu, \& Q. Sun. 2019. Associations of monounsaturated fatty acids from plant and animal sources with total and cause-specific mortality in two US prospctive cohrot studies. Circ. Res. 124: 1266 - 1275. https://doi.org/10.1161/ CIRCRESAHA.118.313996

Gunawan, A., C. Sumantri, \& R. Juniarti. 2017. Gen dan Keragaman Genetik Ternak. IPB Pr, Bogor.

Hartl, D.L. \& A.G. Clark. 1997. Principle of Population Genetic. Sinauer Associates, Sunderland.

He, J., J. Chen, L. Lu, Y. Tian, Z. Tao, D. Wang, J. Li, G. Li, J. Shen, Y. Fu, \& D. Niu. 2011. A novel snp of liver type fatty acid-binding protein gene in duck and its associations with the intramuscular fat. Mol. Biol. Rep. 39: 1073-1077. https://doi.org/10.1007/s11033-011-0833-z

He, J., Y. Tian, J. Li, J. Shen, Z. Tao, Y. Fu, D. Niu, \& L. Lu. 2012. Expression pattern of L-FABP gene in different tissues and its regulation of fat metabolism-related genes in duck. Mol. Biol. Rep. 40: 189-195. https://doi.org/10.1007/ s11033-012-2048-3

Jump, D.B., S. Tripathy, \& C. M. Depner. 2013. Fatty acid-regulated transcription factors in the liver. Annu. Rev. Nutr. 33: 249-269. https://doi.org/10.1146/ annurev-nutr-071812-161139

Kerry, J. P. \& D. Ledward. 2009. Improving The Sensory and Nutritional Quality of Fresh Meat. CRC Press (ENG), Cambridge. https://doi.org/10.1533/9781845695439

Martin, G. G., A. L. McIntosh, H. Huang, S. Gupta, B. P. Atshaves, K. K. Landrock, D. Landrock, A. B. Kier, \& F. Schroeder. 2013. Human liver fatty acid binding protein (L-FABP) T94A variant altres structure, stability, and interaction with fibrates. Biochem. 51: 9347-9357. https://doi. org $/ 10.1021 /$ bi401014k

Nei, M. \& S. Kumar. 2000. Molecular Evolution and Phylogenetics. Oxford Univ Pr., New York.

Noor, R. R. 2010. Genetika Ternak. Penebar Swadaya, Jakarta.

Orellana, C., F. Pena, A. Garcia, J. Perea, J. Martos, V. Domenech, \& R. Acero. 2009. Carcass characteristics, fatty acid composition, and meat quality of Criollo Argentino and Braford steers raised on forage in a semi-tropical region of Argentina. Meat Sci. 81: 57-64. https://doi. org/10.1016/j.meatsci.2008.06.015

Poulsen, N. A., F. Gustavsson, M. Glantz, M. Paulsson, L. B. Larsen, \& M. K. Larsen. 2012. The influence of feed and herd on fatty acid composition in 3 dairy breeds (danish holstein, danish jersey, and swedish red). J. Dairy. Sci. 95: 6362-6371. https://doi.org/10.3168/jds.2012-5820

Praagman, J., L. E. T. Vissers, A. A. Mulligan, A. S. D. Laursen, J. W. J. Beulens, Y. T. van der Schouw, N. J. Wareham, C. P. Hansen, K. T. Khaw, M. U. Jakobsen, \& I. Sluijs. 2019. Consumption of individual saturated fatty acids and the risk of myocardial infarction in a UK and Danish cohort. Int. J. Card. 279: 18-26. https://doi.org/10.1016/j. ijcard.2018.10.064

Roussell, M. A., A. M. Hill, T. L. Gaugler, S. G. West, J. P. V. Heuvel, P. Alaupovic, P. J. Gillies, \& P. M. Kris-Etherton. 2012. Beef in optimal lean diet study: effect on lipids, lipoproteins, and apolipoprotein. Am. J. Clin. Nutr. 95: 9-16. https://doi.org/10.3945/ajen.111.016261

Sambrook, J., J. F. Fritsch, \& T. Maniatis. 1989. Moleculer Cloning: A Laboratory Manual. Cold Spring Harbour Lab Pr., New York.

Viljoen, G.J., H.N. Louis, \& R.C John. 2005. Molecular Diagnostic PCR Handbook. Springer, Dordrecht, Netherland.

Virtanen, J.K., J. Mursu, T. P. Tuomainen, \& S. Voutilainen. 2014. Dietary fatty acids and risk of coronary heart disease in men: the kuopio ischemic heart disease risk factor study. Arterioscler. Thromb. Vasc. Biol. 34:1-9. https://doi. org/10.1161/ATVBAHA.114.304082

Wideman, N., C. A. O'bryan, \& P. G. Crandall. 2016. Factors affecting poultry meat colour and consumer preferences - A review. World's Poult. Sci. J. 72: 353-366. https://doi. org/10.1017/S0043933916000015

Zhang, Y.H., L.S. Dai, T.H. Ma, S.Z. Wang, J. Guo, F.J. Li, S.M. Zhang, B.X. Sun, D.F. Liu, Y. Gao, \& J.B. Zhang. 2013. Association of T1740C polymorphism of L-FABP with meat quality traits in Junmu No.1 white swine. Gen. Mol. Researc. 12: 235-241. https://doi.org/10.4238/2013. January.30.9 